\title{
Phytoremediation of phenol using Polygonum orientale and its antioxidative response
}

\author{
Kai Wang, Jin Cai, Shulian Xie*, Jia Feng, Ting Wang \\ Shanxi University, PR China \\ School of Life Science \\ *Corresponding author's e-mail: xiesl@sxu.edu.cn
}

Keywords: Polygonum orientale, phenol, phytoremediation, antioxidant enzyme, osmotic regulator.

\begin{abstract}
Polygonum orientale with beautiful red flowers can be found as one dominant species in the vicinity of most water bodies and wetlands in China. However, its phytoremediation potential has not been sufficiently explored because little is known about its resistance to inorganic or organic pollutants. We investigated $P$. orientale response to low and moderate levels of phenol stress $\left(\leq 80 \mathrm{mg} \mathrm{L}^{-1}\right)$. Endpoints included phenol tolerance of $P$. orientale and the removal of the pollutant, antioxidant enzyme activities, damage to the cell membrane, osmotic regulators and photosynthetic pigments. In plant leaves, phenol stress significantly increased the activities of peroxidase (POD) and catalase (CAT), as well as the contents of proline, soluble sugars and carotenoids, whereas superoxide dismutase (SOD), $\mathrm{H}_{2} \mathrm{O}_{2}$ and electrolyte leakage (EL) levels remained unaltered. On the other hand, there were significant decreases of soluble protein and chlorophyll contents. We demonstrated that, in combination with phenol tolerance and its removal, $P$. orientale has efficient protection mechanisms against phenol-induced oxidative damage $\left(\leq 80 \mathrm{mg} \mathrm{L}^{-1}\right)$. We propose that $P$. orientale could be used as an alternative and interesting material in the phytoremediation of phenol.
\end{abstract}

\section{Introduction}

Phenol is an aromatic organic compound with a characteristic pungent odor and is highly toxic. The production of phenol arises from the rapid development of chemical industries, such as petrochemicals, paper-making and pharmaceutical products (Jordan et al. 2002). Consequently, phenol contaminated wastewater is being discharged into aquatic environments in China (Yu et al. 2007).

The discharge of phenol into aquatic environments is increasingly restricted (Coniglio et al. 2008). However, Paisio et al. (2009) reported that phenol concentrations in the $50-600 \mathrm{mg} \mathrm{L}^{-1}$ range still occur in aquatic environments. These concentrations may potentially harm the growth and propagation of aquatic species and cause serious health issues in humans (D'Alessandro et al. 2012). Numerous techniques have been developed to eliminate or degrade phenolic contaminants such as distillation, extraction using organic solvents, membrane adsorption and separation. However, there are limitations with these methods, e.g. low efficiency, high cost, toxic compound formation and secondary pollution (Busca et al. 2008).

Phytoremediation is an efficient, economical, eco-friendly and aesthetically advantageous method using plants to enrich, degrade and absorb toxic compounds. There are some successful examples of higher plants for phenol removal (Flocco et al. 2002, Ibáñez et al. 2012, Singh et al. 2008). However, for remediating and beautifying the banks of water bodies in the urban environment, these plant species are still limited. Recently, we screened for phenol resistant plants with ornamental value, including potential protective mechanisms against toxic stress.

Polygonum orientale, present in the vicinity of most wastewater bodies and wetlands in China, could be found as a dominant species with red flowers in the growth area (Yang et al. 2008). It is an annual plant belonging to the Polygonaceae family and has been used as a medicinal plant. However, its potential phytoremediation capability has not been sufficiently explored. We investigated the response of $P$. orientale to low and moderate concentrations of phenol $\left(\leq 80 \mathrm{mg} \mathrm{L}^{-1}\right)$, assessing the removal ratio from culture solution, lipid peroxidation (MDA), activities of antioxidant enzymes including superoxide dismutase (SOD), peroxidase (POD), catalase (CAT), the number of osmotic regulators, as well as the photosynthetic pigments in the leaves. The results could assist in estimating the resistance mechanisms in P. orientale to phenol exposure and its phytoremediation potential.

\section{Experimental procedure}

\section{Plant samples and cultivation}

Plant samples of $P$. orientale were collected from the Fenhe River wetland $\left(37^{\circ} 51^{\prime} \mathrm{N}, 112^{\circ} 30^{\prime} \mathrm{E}\right)$, Taiyuan, Shanxi province, China (Fig. 1a). After diseased and yellowing leaves were removed, the plants were washed. The roots were soaked in $0.1 \% \mathrm{KMnO}_{4}$ for 10 minutes to kill the microorganisms. 
Healthy plant material of similar size (ca. 70-80 cm high and 2.5-3 cm wide) was selected for this experiment. The plants were cultivated in plastic buckets $(25 \mathrm{~cm}$ diameter and $35 \mathrm{~cm}$ deep) with one plant per bucket. The containers were filled with $3 \mathrm{~L}$ of distilled water containing $150 \mathrm{ml}$ of Hoagland nutrient solution ( $\mathrm{pH}$ 6.85). In addition, $30 \mathrm{mg} \mathrm{CuSO}_{4}$ and $30 \mathrm{mg}$ ampicillin were added to the buckets to inhabit algae and other microorganisms (Coyner et al. 2001). Plants were exposed to an outdoor space (ca. $15 \mathrm{~h}$ light/9 h dark; day/night temperature of $30 / 27^{\circ} \mathrm{C}$ and $65 \pm 5 \%$ relative humidity). After 7 day acclimation each bucket had the culture solution renewed. To prepare the phenol culture medium, a stock phenol solution (5 $000 \mathrm{mg} \mathrm{L}^{-1}$ ) was added to each bucket to provide final concentrations of 5, 20 and $80 \mathrm{mg} \mathrm{L}^{-1}$. They were based on a previous inquiry showing that the concentration of phenol in wastewater which discharged into aquatic environments of Fenhe River wetland area ranged from 4.68 to $82.17 \mathrm{mg} \mathrm{L}^{-1}$. And in our preliminary experiment, some abnormal characters of $P$. orientale appeared when the phenol treatments were over $80 \mathrm{mg} \mathrm{L}^{-1}$. Two controls (control 1 with no phenol and control 2 with no plant) were placed under the same conditions. Each treatment (5 mg L-1; $20 \mathrm{mg} \mathrm{L}^{-1} ; 80 \mathrm{mg} \mathrm{L}^{-1}$, control 1 and control 2) was triplicated to minimize experimental error. All of the buckets were sealed with plastic film at the top.

\section{Phenol determination}

The extracted phenol residual from the culture solution was determined using a spectrophotometric assay, with a wavelength of $272 \mathrm{~nm}$ (Wright et al. 1999), evaluated daily for 7 days. A calibration curve was used to analyze the remaining concentration of phenol, based on standardized pure phenol concentrations. Results were expressed as residual phenol, defined as the ratio between the concentration of the phenol removed and its initial concentration. For analysis the value was the mean \pm standard error (SE) of three replicate plants per treatment.

\section{Determination of lipid peroxidation (MDA content), cell membrane permeability (EL) and $\mathrm{H}_{2} \mathrm{O}_{2}$}

Lipid peroxidation of leaves was determined using malondialdehyde (MDA) content (Dhindsa et al. 1981). MDA was measured following the methods of Zhou (2001) with some modifications. Leaves $(0.5 \mathrm{~g})$ were immediately homogenized in $0.25 \%$ thiobarbituric acid, heated at $98^{\circ} \mathrm{C}$ for 30 minutes, then centrifuged at $10000 \times g$ for 10 minutes. The absorbance of the supernatant was measured at 450532 and $600 \mathrm{~nm}$.

Membrane permeability was detected by measuring electrolyte leakage (EL, Jia et al. 2013). The electrolyte leakage was calculated as $\operatorname{EL}(\%)=\mathrm{S}_{1} / \mathrm{S}_{2} \times 100 \%$, where $\mathrm{S}_{1}$ was the initial electric conductance and $\mathrm{S}_{2}$ was the final electric conductance.

$\mathrm{H}_{2} \mathrm{O}_{2}$ content was measured following the methods in Sergiev (1997). The content of $\mathrm{H}_{2} \mathrm{O}_{2}$ was calculated using a standard curve, prepared from diluted commercial $\mathrm{H}_{2} \mathrm{O}_{2}$ of known concentrations. Absorbency was recorded at $240 \mathrm{~nm}$ using the molar extinction coefficient of $43.6 \mathrm{M}^{-1} \mathrm{~cm}^{-1}$.

\section{Antioxidant enzyme activity assays}

One gram of fresh leaf material (without the main midribs) was cut into pieces and homogenized using $1 \mathrm{~mL}$ of chilled
$\mathrm{NaH}_{2} \mathrm{PO}_{4} / \mathrm{Na}_{2} \mathrm{HPO}_{4}$ buffer (PBS, $50 \mathrm{mM}$, pH 7.8) containing $0.1 \mathrm{mM}$ ethylenediaminetetraacetic acid (EDTA) and $1 \%$ polyvinylpyrrolidone (PVP). The homogenate was centrifuged at $12000 \times \mathrm{g}$ for $30 \mathrm{~min}$ at $4^{\circ} \mathrm{C}$ and the resultant supernatant was collected for protein assay and the determination of SOD, POD and CAT activity ( $\mathrm{Li}$ et al. 2013).

SOD activity was estimated using the modified method of Dhindsa and Matowe (Dhindsa et al. 1981). The reaction mixture consisted of $50 \mathrm{mM}$ PBS (pH 7.8), $13 \mathrm{mM}$ methionine, $75 \mu \mathrm{M}$ nitroblue tetrazolium (NBT), $0.1 \mathrm{mM}$ EDTA-Na ${ }_{2}$ and $3 \mathrm{~mL}$ enzyme extraction. The reaction was started by adding $50 \mu \mathrm{L}$ of $2 \mu \mathrm{M}$ lactochrome. After 10 minute illumination at $25^{\circ} \mathrm{C}$ using a non-illumination surface as reference, the absorbance was measured at $550 \mathrm{~nm}$. The dark control was the complete reaction medium without the enzyme incubated in the dark. One unit of enzyme activity was defined as the quantity of SOD required to produce a $50 \%$ inhibition in the reduction of NBT and the results were recorded as a unit of SOD activity per milligram of protein ( $\mathrm{U} \mathrm{mg}^{-1}$ protein).

POD activity was measured following the modified method of Prado et al. (2012). We added $100 \mu \mathrm{L}$ of supernatant to the $2 \mathrm{~mL}$ reaction mixture containing $50 \mathrm{mM}$ potassium phosphate buffer ( $\mathrm{pH} 6.0$ ), $1 \%$ guaiacol and $0.4 \% \mathrm{H}_{2} \mathrm{O}_{2}$. Guaiacol oxidation was recorded at $420 \mathrm{~nm}$ against a blank without $\mathrm{H}_{2} \mathrm{O}_{2}$. POD activity was expressed as $\mathrm{U} \mathrm{mg}^{-1}$ protein. The unit of POD was defined as the amount of enzyme causing the formation of $1 \mu \mathrm{mol}$ tetraguaiacol per minute using a molar extinction coefficient of $26.6 \mathrm{nM}^{-1} \mathrm{~cm}^{-1}$.

To measure CAT activity, the enzyme extraction was added to $3 \mathrm{~mL} 50 \mathrm{nM}$ PBS buffer ( $\mathrm{pH} 7.0$ ) and incubated at $25^{\circ} \mathrm{C}$. After 5 minutes the reaction was started by adding $0.02 \mathrm{~mL} 6 \mu \mathrm{M}$ $\mathrm{H}_{2} \mathrm{O}_{2}$ with the absorbance changes recorded at $240 \mathrm{~nm}$ against a blank without $\mathrm{H}_{2} \mathrm{O}_{2}$ for $1 \mathrm{~min}$. The result of CAT activity was expressed as $\mathrm{U} \mathrm{mg}^{-1}$ protein $^{-1}$. One CAT unit was defined as the enzyme activity that decomposed $1 \mu \mathrm{mol}$ of $\mathrm{H}_{2} \mathrm{O}_{2}$ per min using a molar extinction coefficient of $39.4 \mathrm{mM}^{-1} \mathrm{~cm}^{-1}$ (Abei et al. 2013). The antioxidant enzyme activity was measured on the 1st, 3rd, 5th and 7 th days of the experiment.

\section{Determination of osmotic regulators}

The soluble protein, proline and soluble sugar contents were selected as the osmotic regulators. They were determined on the $1 \mathrm{st}, 3 \mathrm{rd}, 5 \mathrm{th}$ and 7 th days. Soluble protein was determined using Bradford's methods (Bradford 1976) with bovine serum albumin as a standard and Coomassie brilliant blue as colorant.

Proline content of leaves was estimated following the method of Bates et al. for free proline determination (Bates et al. 1973). Plant samples (0.5 g) were homogenized in $10 \mathrm{ml}$ $3 \%$ sulfosalicylic acid and heated at $100^{\circ} \mathrm{C}$ for $10 \mathrm{~min}$. After centrifugation at $3000 \times g$ for $5 \mathrm{~min}$, the supernatant $(2 \mathrm{~mL})$ was mixed with $2 \mathrm{~mL}$ glacial acetic and $2 \mathrm{~mL}$ acid-ninhydrin reagent in a test tube and then heated for $30 \mathrm{~min}$ at $100^{\circ} \mathrm{C}$. After the reaction was terminated using an ice bath, the mixture was extracted with $4 \mathrm{~mL}$ of toluene. The absorbance was recorded at $520 \mathrm{~nm}$ using toluene as a blank. Proline concentration was determined using a standard curve as ug $\mathrm{g}^{-1} \mathrm{FW}$.

Sugars were determined following Li's method (Bates et al. 1973). Leaf dry tissue was extracted using distilled water. In a test tube, $1 \mathrm{~mL}$ of the carbohydrate extract was mixed with $9 \mathrm{~mL}$ anthrone sulfuric acid reagent, and then heated at $100^{\circ} \mathrm{C}$ for 30 minutes. The absorbance was measured at 
$630 \mathrm{~nm}$ against a blank containing distilled water and anthrone reagent. Soluble sugar concentration was determined using a calibration curve prepared with sucrose solution.

\section{Determination of chlorophyll and carotenoids}

To determine chlorophyll and carotenoid content we used $0.2 \mathrm{~g}$ of fresh leaf material (without the main midribs) soaked in $25 \mathrm{ml} \mathrm{95 \%}(\mathrm{V} / \mathrm{V})$ ethanol at $4{ }^{\circ} \mathrm{C}$ in darkness until the tissue turned white. Using the spectrophotometer we determined chlorophyll $a, b$ and carotenoid contents in extracts at 649, 665 and $470 \mathrm{~nm}$, respectively. These data were collected on day 1 , 3,5 and 7, and calculated following the equations described by Lichtenthaler and Wellburn (Bates et al. 1973).

\section{Data analysis}

Data were analyzed using Excel 2010 and SPSS 16.0 software. The analyzed values were expressed as means \pm standard error (SE). Data were analyzed using one-way analysis of variance (ANOVA) with the Duncan's multiple range tests to separate means. All figures were created using Excel 2010 and Photoshop CS5 software.

\section{Results}

\section{Phenol tolerance of $P$. orientale and the removal of the pollutant}

The residual phenol extracted from culture solution was invested to determine the phenol removal efficiency. For plants exposed to $80 \mathrm{mg} \mathrm{L}^{-1}$ of phenol, the residual amount of phenol was $57.3 \%$, while at $20 \mathrm{mg} \mathrm{L}^{-1}$ it consistently decreased to $33.07 \%$ at the end of the experiment (Fig. 1). However, the residual phenol at $5 \mathrm{mg} \mathrm{L}^{-1}$ dropped sharply, reaching a removal percentage of approximately $100 \%$ after 5 days (Fig. 1). In addition, no phenol was found in control 1 and only $0.2 \mathrm{mg} \mathrm{L}^{-1}$ of phenol reduction was determined in control 2.

\section{The effect of phenol on lipid peroxidation, electrolyte leakage and $\mathrm{H}_{2} \mathrm{O}_{2}$ contents}

MDA values in $P$. orientale leaves under the three increasing phenol exposure showed similar trends. There were no

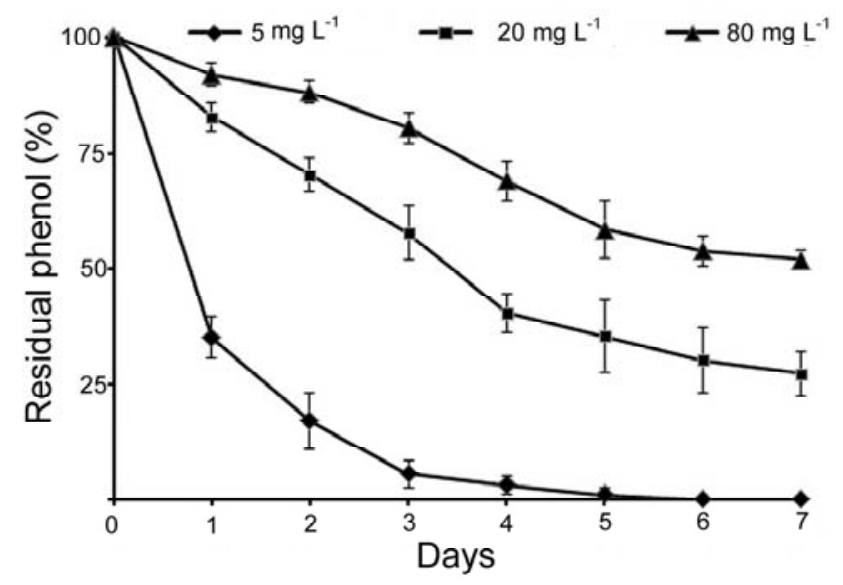

Fig. 1. Removal efficiency of phenol. The variation in phenol removal in culture solution by Polygonum orientale plants treated for 7 days with three different phenol concentrations. Each data point represents the average of three replicates, and vertical bars indicate mean $\pm \mathrm{SE}$ significant differences $(\mathrm{P}>0.05)$ between the treated and untreated plants (Fig. 2a).

The extent of cell membrane damage estimated using leaf electrolyte leakage was similar to the variations in MDA content. The ion leakage in $P$. orientale leaves varied slightly showing a fluctuating trend, but no significant difference occurred compared with the control ( $\mathrm{P}>0.05$; Fig. 2b).

When we analyzed $\mathrm{H}_{2} \mathrm{O}_{2}$ levels, only plants exposed to $80 \mathrm{mg} \mathrm{L}^{-1}$ showed a significant increase in leaves after a 5-day exposure $(\mathrm{P}<0.05)$. However, there was no significant difference observed at day 7 ( $\mathrm{P}>0.05$; Fig. $2 \mathrm{c})$.

\section{The effect of phenol on antioxidant enzyme activity}

The SOD activity in leaf of plants exposed to $5 \mathrm{mg} \mathrm{L}^{-1}$ of phenol was slightly higher than that of the control group during the experiment (Fig. 3a). However, we found no significant difference in SOD activity between the treatments and the control $(\mathrm{P}>0.05)$.

In the first $24 \mathrm{~h}$, only plants exposed to the highest phenol concentration $\left(80 \mathrm{mg} \mathrm{L}^{-1}\right)$ showed a significant increase of POD activity compared with the control (Fig. 3b). The POD activity in the leaves of plants from the other two phenol treatments increased smoothly as phenol concentration increased. Until day three, significant differences in POD

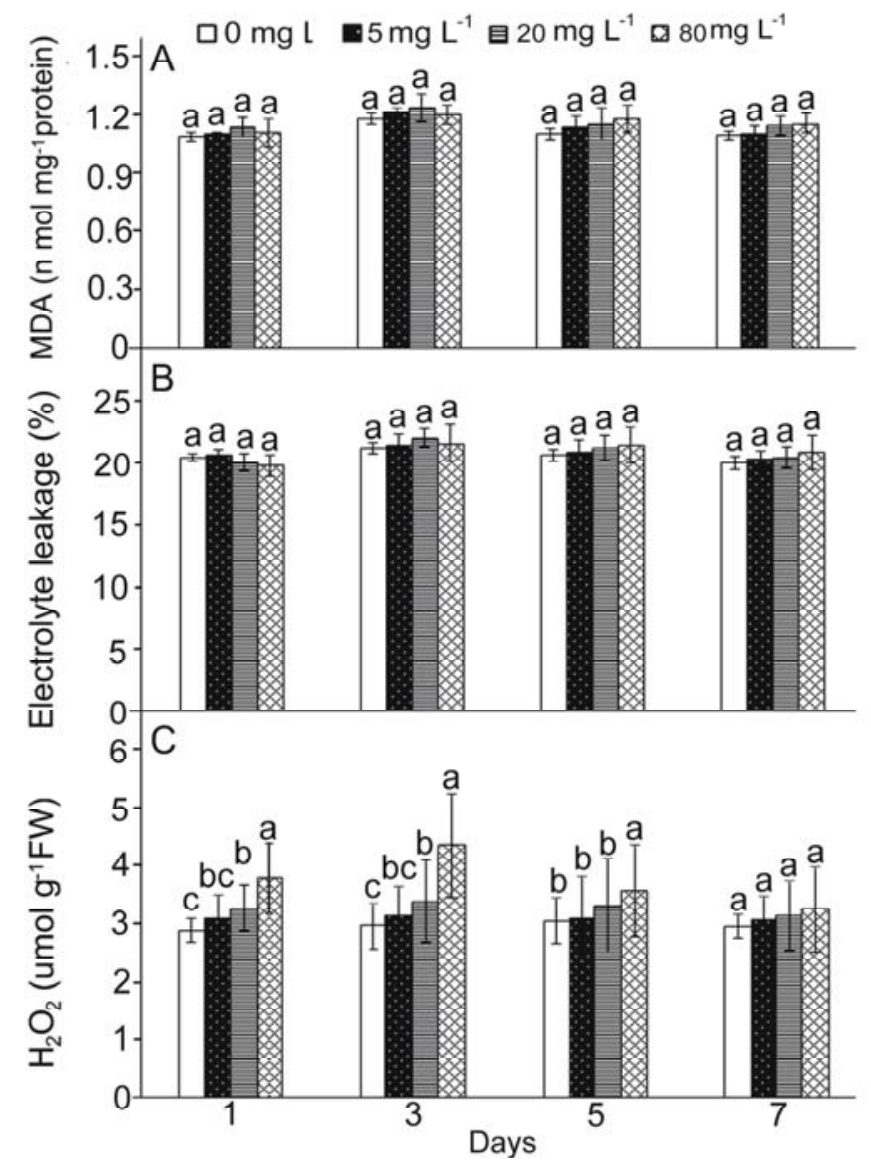

Fig. 2. Parameters for damage of cell membrane.

The variation in MDA levels (a), electrolyte leakage (b) and $\mathrm{H}_{2} \mathrm{O}_{2}$ content (c) in the leaves of Polygonum orientale treated with four different phenol concentrations after 1, 3, 5 and

7 days. Data are presented as means \pm SE of three replicates. Different letters indicate significantly different values according to Duncan's multiple range test $(P<0.05)$. 
activity were observed in each treatment $(\mathrm{P}<0.05)$. From day 3 to 5 , these values for each phenol treatment maintained higher level compared with the control. After day 5, POD levels then decreased in each phenol treated group until day 7. After this, plants exposed to $80 \mathrm{mg} \mathrm{L}^{-1}$ had higher levels of POD activity in their leaves, compared with $5 \mathrm{mg} \mathrm{L}^{-1}$ group and $20 \mathrm{mg} \mathrm{L}^{-1}$ group which converged close to the control level.

At day 1, foliar CAT activity significantly peaked $(\mathrm{P}<0.05$; Fig. $3 \mathrm{c})$ for plants exposed to $5 \mathrm{mg} \mathrm{L}^{-1}$ phenol compared to the control ones and then gradually decreased at higher exposures. From day 5, foliar CAT activity did not differ between the $5 \mathrm{mg} \mathrm{L}^{-1}$ phenol treatment and the control ( $\mathrm{P}>0.05$ ). At $20 \mathrm{mg} \mathrm{L}^{-1}$ phenol it peaked on day 3, whereas at $80 \mathrm{mg} \mathrm{L}^{-1}$ its maximum values were reached on days 5 and 7. Overall, foliar CAT activity in each treatment showed an initial increase, and then decreased over time.

\section{The effect of phenol on osmotic regulators}

The soluble protein contents in leaves of plants treated with 20 and $80 \mathrm{mg} \mathrm{L}^{-1}$ phenol decreased significantly compared with the control in the first 3 days, but the values increased from day 3 to day 7 (Fig. 4). Foliar protein content in plants treated with $5 \mathrm{mg} \mathrm{L}^{-1}$ was consistently higher compared with the control over the first 3 days $(\mathrm{P}<0.05$; Fig. $4 \mathrm{a})$. However, at day 7 , there was no significant difference in the 5 and $20 \mathrm{mg} \mathrm{L}^{-1}$ treatments compared with the control $(\mathrm{P}>0.05)$.

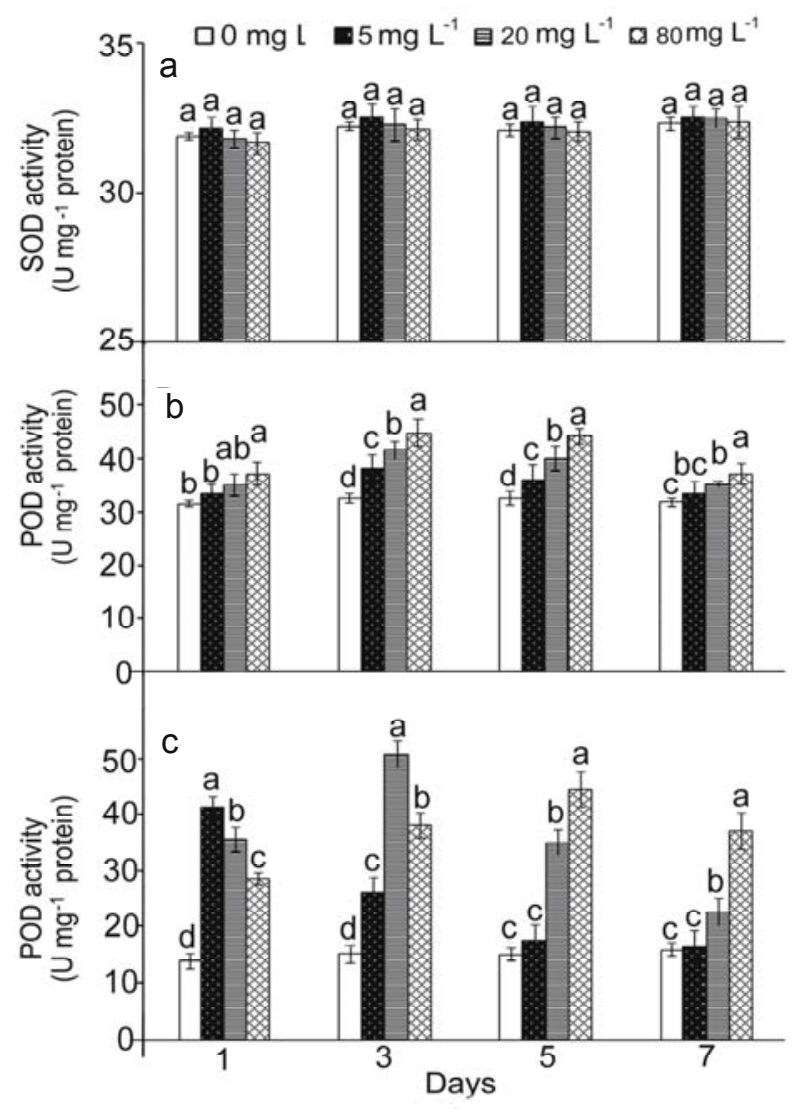

Fig. 3. Variations of antioxidative enzymes. Variations in activities of SOD (a), POD (b) and CAT (c) in leaves of

Polygonum orientale treated with four different concentrations of phenol after 1, 3, 5 and 7 days. Data are presented as means \pm SE of three replicates. Different letters indicate significantly different values according to Duncan's multiple range test $(P<0.05)$.
Foliar free-proline concentration generally increased as phenol exposure rose (Fig. 4b). These values increased for 3 days before decreasing slightly. On day $5,80 \mathrm{mg} \mathrm{L}^{-1}$ group reached the maximum $15.64 \mathrm{mg} \mathrm{g}^{-1}$ level (2.05 fold higher than the control). During the 3rd and 5th day, significant differences were displayed by plants in each phenol treated group compared with the plants in control group (Fig. 4b).

Foliar soluble sugar content generally significantly increased for plants exposed to phenol $(\mathrm{P}<0.05$; Fig. $4 \mathrm{c})$. The lowest phenol treatment $\left(5 \mathrm{mg} \mathrm{L}^{-1}\right)$ showed a rapid increase within 3 days, followed by a decline. Plants treated with $20 \mathrm{mg}$ $\mathrm{L}^{-1}$ of phenol showed a similar trend up to day 3 , followed by a slow decline. We found that plants exposed to $20 \mathrm{mg} \mathrm{L}^{-1}$ of phenol showed the highest soluble sugar content across all treatments. In contrast, foliar soluble sugar content in plants treated with $80 \mathrm{mg} \mathrm{L}^{-1}$ phenol showed a relative slow increase compared with the other two treatments, with a numerical-wave trend observed during the experiment (Fig. 4c).

\section{The effect of phenol on photosynthetic pigments}

Phenol stress altered chlorophyll and carotenoids content in $P$. orientale leaves (Table 1). In the first 3 days, we found significant differences in chlorophyll content (chl $a, \operatorname{chl} b$ and chl $a+b)$ showing a downward trend $(\mathrm{P}<0.05)$. The groups in order of decreasing chlorophyll content (chl $a$, chl $b$ and chl $a+b)$ were $80 \mathrm{mg} \mathrm{L}^{-1}$ group $>20 \mathrm{mg} \mathrm{L}^{-1}$ group $>5 \mathrm{mg} \mathrm{L}^{-1}$ group,

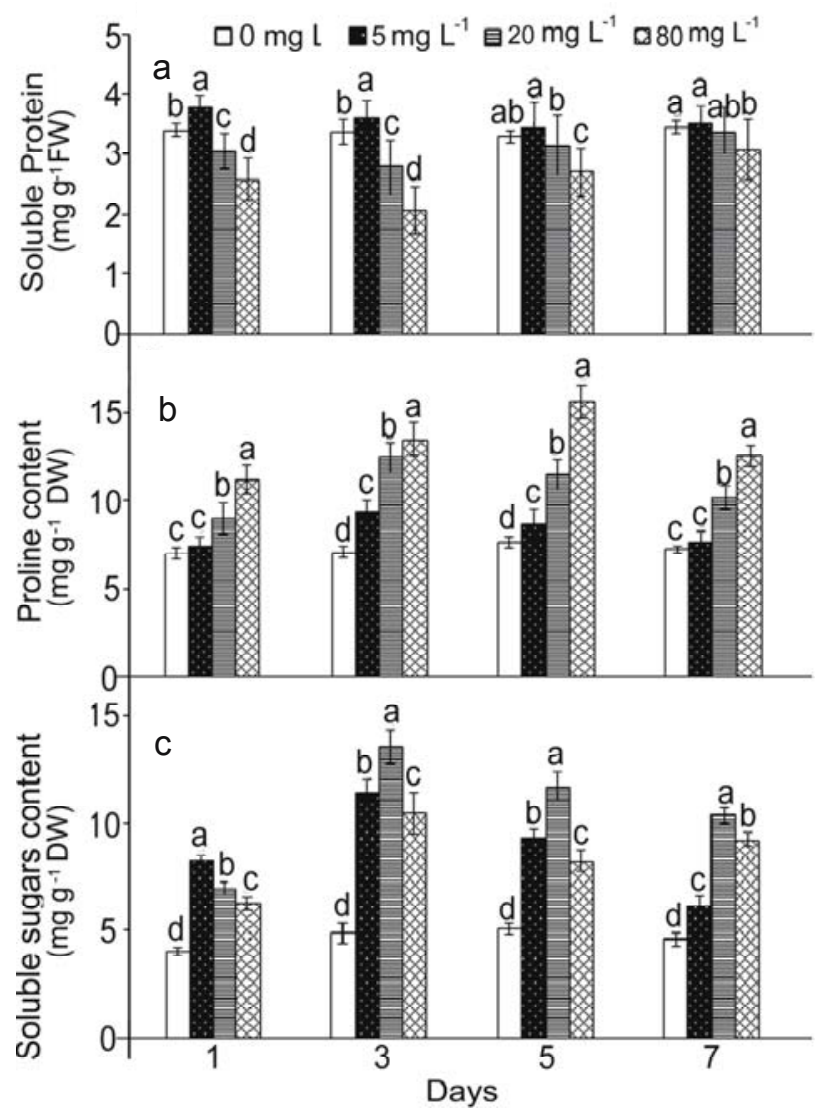

Fig. 4. Variations of osmotic regulators. Variations of total soluble protein contents (a), proline contents (b), and soluble sugars contents (c) in leaves of Polygonum orientale treated with different concentrations of phenol after 1, 3, 5 and 7 days. Data are presented as means \pm SE of three replicates. Different letters indicate significantly different values according to Duncan's multiple range test $(P<0.05)$ 
respectively. Subsequently, the chlorophyll content in 5 and $20 \mathrm{mg} \mathrm{L}^{-1}$ groups recovered respectively, with no significant differences compared with the control on day $7(\mathrm{P}>0.05)$. The chlorophyll content of $80 \mathrm{mg} \mathrm{L}^{-1}$ group showed a relatively smooth recovery, with a significant difference compared with the control $(\mathrm{P}<0.05)$ to day 7 . For chlorophyll $a / b$, we found a significant decrease $(\mathrm{P}<0.05)$ with plants under higher phenol stress (20 and $\left.80 \mathrm{mg} \mathrm{L}^{-1}\right)$. Conversely, carotenoid levels showed a significant increase $(\mathrm{P}<0.05)$ in plants under moderate to high phenol stress $\left(\geq 20 \mathrm{mg} \mathrm{L}^{-1}\right.$ ) for the first 5 days, followed by a gradual decrease.

\section{Discussion}

\section{Phenol tolerance of $P$. orientale and the removal of the pollutant}

Phenol disrupts metabolic and growth processes in plants, although different plant species have a diversity of responses to this compound (Flocco et al. 1973, González et al. 1973). Consequently, the concept that $P$. orientale could detoxify and simultaneously maintain normal plant metabolism requires investigation. The time required to achieve this phytoremediation process also requires further research. In hydroponics, $P$. orientale can remove $5 \mathrm{mg} \mathrm{L}^{-1}$ phenol in 5 days (Fig. 1). This agrees with the response of Vetiveria zizanoides L. Nash (Singh et al. 2008). However, as the phenol concentration increased, the removal rate dropped below $50 \%$ and more time was needed to achieve a better removal. This confirms previous findings with other plant species such as alfalfa (Medicago sativa L.), which removed $100 \%$ of $100 \mathrm{mg}$ $\mathrm{L}^{-1}$ phenol in 30 days (Flocco et al. 2002). In addition, as the removal rate caused by physical mechanisms like evaporation was too small in this study, it could be considered as minority or even depreciable. Above all, we indicated that $P$. orientale could tolerate phenol stress under the concentration below $80 \mathrm{mg} \mathrm{L}^{-1}$ and it maintained a relatively effective removal rate.

\section{Analysis on the damage of cell membrane}

The accumulation of malondialdehyde (MDA) is an integrated indicator of lipid peroxidation (Smirnoff 1993). According to Mittler's report (Mittler 2002), high $\mathrm{H}_{2} \mathrm{O}_{2}$ levels could accelerate the Haber-Weiss reaction, resulting in the formation and prompting of lipid peroxidation. In addition, ion leakage levels are an important manifestation of membrane damage during plant stress (Turkan et al. 2005). Thus, increases in MDA, $\mathrm{H}_{2} \mathrm{O}_{2}$ and EL indicate cell damage (Jia et al. 2013, Wang et al. 2012). Leaf MDA content and electrolyte leakage did not vary between treated and untreated P. orientale plants. Consequently, the structure and function of cell membranes would be unaffected by low and moderate phenol concentrations (below $80 \mathrm{mg} \mathrm{L}^{-1}$ ). Significant increase in foliar $\mathrm{H}_{2} \mathrm{O}_{2}$ content at higher phenol concentrations only appeared for a short time during the experiment. This suggests the occurrence of effective defensive mechanisms either preventing or removing $\mathrm{H}_{2} \mathrm{O}_{2}$. Our findings imply that at phenol concentrations $\leq 80 \mathrm{mg} \mathrm{L}^{-1} P$. orientale plants can tolerate or avoid cellular level damage and maintain normal metabolism.

\section{Antioxidative response of $P$. orientale treated with phenol}

The antioxidant system in plants results from sequential and simultaneous actions by several antioxidant enzymes such as

Table 1. Changes of photosynthetic pigments (Foliar chlorophyll $a$, chlorophyll $b$, chlorophyll $a+b$, chlorophyll $a / b$ and carotenoid content in Polygonum orientale plants exposed to increasing levels of phenol, at day 1, 3, 5 and 7 after the exposure.)

\begin{tabular}{|c|c|c|c|c|c|c|}
\hline \multirow{2}{*}{ Days } & \multirow{2}{*}{$\begin{array}{l}\text { phenol stress } \\
\left(\mathrm{mg} \mathrm{L}^{-1}\right)\end{array}$} & chl a & chl $b$ & $\operatorname{chl} a+b^{b}$ & $\mathrm{chl} a / b^{c}$ & Carotenoid \\
\hline & & $\left(\mathrm{mg} \mathrm{g}^{-1} \cdot \mathrm{FW}\right)$ & $\left(\mathrm{mg} \mathrm{g}^{-1} \cdot \mathrm{FW}\right)$ & $\left(\mathrm{mg} \mathrm{g}^{-1} \cdot \mathrm{FW}\right)$ & $(\%)$ & $\left(\mathrm{mg} \mathrm{g}^{-1} \cdot \mathrm{FW}\right)$ \\
\hline \multirow{4}{*}{1} & 0 & $17.52 \pm 0.01 \mathrm{a}^{\mathrm{a}}$ & $6.58 \pm 0.03 \mathrm{a}$ & $24.10 \pm 0.04 \mathrm{a}$ & $2.67 \pm 0.05 \mathrm{a}$ & $2.92 \pm 0.05 \mathrm{c}$ \\
\hline & 5 & $17.09 \pm 0.04 b$ & $6.25 \pm 0.04 b$ & $23.34 \pm 0.08 \mathrm{a}$ & $2.73 \pm 0.15 a$ & $3.02 \pm 0.02 b c$ \\
\hline & 40 & $14.44 \pm 0.05 \mathrm{c}$ & $6.20 \pm 0.07 \mathrm{~b}$ & $20.64 \pm 0.12 b$ & $2.33 \pm 0.21 b$ & $3.98 \pm 0.03 b$ \\
\hline & 80 & $12.27 \pm 0.04 \mathrm{~d}$ & $5.86 \pm 0.03 c$ & $18.13 \pm 0.07 \mathrm{c}$ & $2.09 \pm 0.86 \mathrm{c}$ & $4.69 \pm 0.07 \mathrm{a}$ \\
\hline \multirow{4}{*}{3} & 0 & $17.61 \pm 0.06 \mathrm{a}$ & $6.54 \pm 0.01 \mathrm{a}$ & $24.15 \pm 0.07 \mathrm{a}$ & $2.69 \pm 0.03 a$ & $2.97 \pm 0.16 \mathrm{~d}$ \\
\hline & 5 & $16.89 \pm 0.08 \mathrm{~b}$ & $6.48 \pm 0.03 \mathrm{a}$ & $23.37 \pm 0.12 b$ & $2.61 \pm 0.12 \mathrm{a}$ & $3.17 \pm 0.02 \mathrm{c}$ \\
\hline & 40 & $13.91 \pm 0.08 \mathrm{c}$ & $5.95 \pm 0.02 b$ & $19.86 \pm 0.10 \mathrm{c}$ & $2.33 \pm 0.09 \mathrm{~b}$ & $4.74 \pm 0.01 \mathrm{~b}$ \\
\hline & 80 & $11.75 \pm 0.06 \mathrm{~d}$ & $5.74 \pm 0.02 \mathrm{c}$ & $17.49 \pm 0.08 \mathrm{~d}$ & $2.05 \pm 0.04 \mathrm{c}$ & $5.21 \pm 0.07 \mathrm{a}$ \\
\hline \multirow{4}{*}{5} & 0 & $17.65 \pm 0.03 \mathrm{a}$ & $6.62 \pm 0.02 \mathrm{a}$ & $24.27 \pm 0.05 a$ & $2.67 \pm 0.04 \mathrm{a}$ & $2.95 \pm 0.04 \mathrm{c}$ \\
\hline & 5 & $17.47 \pm 0.14 \mathrm{a}$ & $6.58 \pm 0.03 \mathrm{a}$ & $24.05 \pm 0.16 \mathrm{a}$ & $2.66 \pm 0.16 \mathrm{a}$ & $3.03 \pm 0.10 \mathrm{c}$ \\
\hline & 40 & $15.17 \pm 0.03 b$ & $6.14 \pm 0.03 b$ & $21.31 \pm 0.06 b$ & $2.47 \pm 0.11 b$ & $4.09 \pm 0.04 b$ \\
\hline & 80 & $12.46 \pm 0.06 \mathrm{c}$ & $5.81 \pm 0.08 \mathrm{c}$ & $18.27 \pm 0.14 \mathrm{c}$ & $2.14 \pm 0.05 \mathrm{c}$ & $5.73 \pm 0.10 \mathrm{a}$ \\
\hline \multirow{4}{*}{7} & 0 & $17.64 \pm 0.06 \mathrm{a}$ & $6.59 \pm 0.01 \mathrm{a}$ & $24.23 \pm 0.07 a$ & $2.68 \pm 0.06 \mathrm{a}$ & $2.97 \pm 0.11 \mathrm{c}$ \\
\hline & 5 & $17.54 \pm 0.02 \mathrm{a}$ & $6.53 \pm 0.02 \mathrm{a}$ & $24.07 \pm 0.05 \mathrm{a}$ & $2.69 \pm 0.04 \mathrm{a}$ & $2.99 \pm 0.17 \mathrm{c}$ \\
\hline & 40 & $17.39 \pm 0.05 a$ & $6.49 \pm 0.04 \mathrm{a}$ & $23.88 \pm 0.09 a$ & $2.68 \pm 0.09 \mathrm{a}$ & $3.33 \pm 0.11 \mathrm{~b}$ \\
\hline & 80 & $15.13 \pm 0.09 b$ & $6.04 \pm 0.03 b$ & $21.17 \pm 0.13 b$ & $2.51 \pm 0.16 b$ & $4.79 \pm 0.03 a$ \\
\hline
\end{tabular}

\footnotetext{
a Values followed by different lowercase letters for a given treatment are significantly different at $P<0.05$

${ }^{\mathrm{b}} a+b$ the summation of chlorophyll $a$ and chlorophyll $b$

${ }^{c} a / b$ the content of chlorophyll $a$ to the content of chlorophyll $b$
} 
SOD, CAT and POD. Because SOD can disproportionate $\mathrm{O}_{2}$ into $\mathrm{O}_{2}$ and $\mathrm{H}_{2} \mathrm{O}_{2}$, SOD is considered the first defensive line playing a key role in scavenging ROS, protecting cells in higher plants. High SOD activity has been associated with stress tolerance in plants where the overproduction of $\mathrm{O}_{2}^{-}$occurs (Scebba et al. 1999). However, we found no significant change in SOD activity in response to the presence of the xenobiotic. This result was similar to Ibáñez et al. (2012) on Vicia sativa L. Therefore, we indicated that the maintenance of constant SOD levels could suffice, ensuring the plant protection against excess $\mathrm{O}_{2}$ - induced by low and moderate levels of phenol (<80 mg L L ${ }^{-1}$, Ibáñez et al. 2012).

The accumulated $\mathrm{H}_{2} \mathrm{O}_{2}$ can be scavenged and converted into water and oxygen by POD and CAT (Gill and Tuteja 2010). POD is an oxidoreductive enzyme related to the metabolism of phenol (Flocco et al. 2002). POD is the primary $\mathrm{H}_{2} \mathrm{O}_{2}$-scavenging enzyme that detoxifies $\mathrm{H}_{2} \mathrm{O}_{2}$ in the chloroplasts and cytosol of the plant cells (Zhang et al. 2011). CAT is an enzyme in cells that catalyzes rapid $\mathrm{H}_{2} \mathrm{O}_{2}$ decomposition (Tayefi-Nasrabadi et al. 2011). Both enzymes constitute the main $\mathrm{H}_{2} \mathrm{O}_{2}$ scavenging system in plant cells. Foliar CAT activity in $P$. orientale increased sharply in the early period of phenol treatment, with a significant decline as phenol concentrations were reduced in the culture solutions (Fig. 3). Conversely, POD activity showed a different response. The delayed response indicates that POD was less sensitive than CAT in phenol stress. Foliar POD played a significant role at the latter part of the experiment (3-7 days) especially under the highest phenol concentration $\left(80 \mathrm{mg} \mathrm{L}^{-1}\right)$. The increase of foliar POD and CAT activities in association with relatively small $\mathrm{H}_{2} \mathrm{O}_{2}$ levels implies the presence of an effective scavenging system to protect cells from oxidative damage. Furthermore, POD and CAT play a key role in sequentially scavenging for $\mathrm{H}_{2} \mathrm{O}_{2}$. These underlying mechanisms require further investigation.

\section{The amount of osmotic regulators}

The accumulation of organic osmolytes such as soluble protein, free proline and soluble sugars is a well-characterized biochemical response of plant cells to stress conditions (Hare, and Cress 1997).

Our present study indicated that higher phenol stress $\left(\geq 20 \mathrm{mg} \mathrm{L}^{-1}\right)$ significantly decreased soluble protein in $P$. orientale leaves for 3 days. This result is similar to Lemna polyrrhiza L. (John et al. 2008) and Phaseolus vulgaris L. (Bhardwaj et al. 2009) when plants were under heavy metal stress. These results might occur from the oxidative damage to plants through the formation of reactive oxygen, causing damage to proteins and chlorophyll (Xu et al. 2013). However, soluble protein stimulation in leaves, induced by a low concentration of phenol stress ( $\leq 5 \mathrm{mg} \mathrm{L}^{-1}$; Fig. 4), might be associated to the increase of various antioxidant enzymes during the experiment.

Proline response has been investigated in different plant species (Kuldeep and Rana 2012, Li et al. 2013, Prado et al. 2012). This amino acid controls osmotic adjustment in relation to different types of environmental stress, with one possible role in conferring stress resistance. Among these roles, balancing capacity as an osmolyte stabilizing protein, regulating cytosolic $\mathrm{pH}$ and scavenging of hydroxyl radicals have been investigated (Kishor et al. 2005). The protective action of proline is thought to be connected with its ability to detoxify
ROS (Tripathi and Gaur 2004) and to inhibit lipid peroxidation (Mehta and Gaur 1999). We found that foliar proline content increased in $P$. orientale plants exposed to phenol, especially over $20 \mathrm{mg} \mathrm{L}^{-1}$. Proline may play a role in osmoregulation and osmotolerance. $P$. orientale appears to have relatively stronger self-protection from proline bioaccumulation. Kuldeep et al. found similar results in Ricinus communis and Brassica juncea where salinity and drought affected cadmium-contaminated soil (Kuldeep and Rana 2012). Apart from proline's direct function as ROS scavenger, the protective action of proline is thought to be connected with its ability to protect and stabilize ROS scavenging enzymes and activate other alternative detoxification pathways (Szabados and Savoure 2010). Our results suggest that proline production is coordinated with the unaltered MDA, with the notable increase in activity of antioxidant enzymes in $P$. orientale.

Soluble sugars accumulation in response to plant stress is widely accepted (Latef et al. 2010). These sugars have multiple roles, such as energy providers for general metabolism and the synthesis of new stress-responsive compounds, they are also available as osmoprotectants (Leslie et al. 1995). Increased phenol concentrations (ca. $20 \mathrm{mg} \mathrm{L}^{-1}$ ) may promote the accumulation of soluble sugars. Conversely, the numerical-wave trend caused by the $80 \mathrm{mg} \mathrm{L}^{-1}$ phenol level may indicate some disturbance.

\section{Changes of photosynthetic pigments}

Changes in chloroplasts are considered an important index in estimating plant response to environmental stress (Strzałka et al. 1995). We found that phenol stress caused a decrease in Chl $a$, Chl $b, \mathrm{Chl}(a+b)$ and Chl $a / b$, especially when the phenol concentration reached $80 \mathrm{mg} \mathrm{L}^{-1}$. This may be attributed to chloroplast disorganization and photosynthesis alteration ( $\mathrm{Li}$ et al. 2000, Parlak and Yilmaz 2013). The chlorophyll content in $\operatorname{chl} a, \operatorname{chl} b$ and chl $a+b$ decreased until day 5 of the experiment (Tab. 1). This could be attributed to reduction in the synthesis rate of chlorophyll and physiological stress from chlorophyll decay (Latef et al. 2010). The decline in chl $a$ was significantly greater than chl $b$, based on the significant decrease in chl $a / b$ values. We suggest that $\operatorname{chl} a$ is more sensitive to phenol stress than chl $b$. Chlorophyll content (chl $a$, chl $b$ and chl $a+b$ ) recovered after 5 days (Tab. 1), attributing this result to $P$. orientale adapting to phenol stress. Carotenoids play a role in protecting the photosynthetic apparatus against ROS when induced by various environmental factors (Strzałka et al. 2003). In this study, carotenoid content showed a significant increase, suggesting that there is a photo-protective mechanism in $P$. orientale to avoid damage caused by ROS.

\section{Conclusion}

1) Polygonum orientale can tolerate phenol stress $\leq 80 \mathrm{mg} \mathrm{L}^{-1}$, according to the result showing no damages in this concentration range of phenol. 2) $P$. orientale can remove $5 \mathrm{mg} \mathrm{L}^{-1}$ of phenol in a short time (5days), and the removal efficiency decreases with the phenol concentration increase. 3) The multiple mechanisms including antioxygenation of enzymes, osmotic adjustment and photo-protective mechanisms enable $P$. orientale to avoid oxidative damages induced by phenol. Finally, considering the overall response from $P$. orientale to low or moderate phenol stress $\left(0-80 \mathrm{mg} \mathrm{L}^{-1}\right)$, we suggest that $P$. orientale is phenol 
tolerant and could be used as a new phytoremediation material to establish a plant-based remediation strategy.

\section{Acknowledgement}

We thank Dean O'Connell (University of Otago, New Zealand) for his critical reviews of the manuscript and editorial assistance with English. This work was supported by Natural Science Foundation of Shanxi (no. 2011011036 to Shulian Xie) and Young Science Foundation of Shanxi (no. 2010021027-2 to Jia Feng).

\section{References}

Abei, H. (1984). Catalase in vitro, Methods in Enzymology, 105, pp. 121-126.

Bates, L.S., Waldren, R.P. \& Teare, I.D. (1973). Rapid determination of free proline for water-stress studies, Plant and Soil, 39, 1, pp. 205-207.

Bhardwaj, P., Chaturvedi, A.K. \& Prasad, P. (2009). Effect of enhanced lead and cadmium in soil on physiological and biochemical attributes of Phaseolus vulgaris L., Nature and Science, 7, 8, pp. 63-75.

Bradford, M.M. (1976). A rapid and sensitive method for the quantitation of microgram quantities of protein utilizing the principle of protein-dye binding, Analytical Biochemistry, 72, 1, 248-254.

Busca, G., Berardinelli, S., Resini, C. \& Arrighi, L. (2008). Technologies for the removal of phenol from fluid streams: a short review of recent developments, Journal of Hazardous Materials, 160, 2, pp. 265-288.

Coniglio, M.S., Busto, V.D., Gonzáles, P.S., Medina, M.I., Milrad, S. \& Agostini, E. (2008). Application of Brassica napus hairy root cultures for phenol removal from aqueous solutions, Chemosphere, 72, 7, pp. 1035-1042.

Coyner, A., Gupta, G. \& Jones, T. (2001). Effect of chlorsulfuron on growth of submerged aquatic macrophyte Potamogeton pectinatus (sago pondweed), Environmental Pollution, 111,3 , pp. 453-455.

D’Alessandro, O., Thomas, H.J. \& Sambeth, J.E. (2012). An analysis of the first steps of phenol adsorption-oxidation over coprecipitated Mn-Ce catalysts: a DRIFTS study, Reaction Kinetics, Mechanisms and Catalysis, 107, 2, pp. 295-309.

Dhindsa, R.S. \& Matowe, W. (1981). Drought tolerance in two mosses: correlated with enzymatic defence against lipid peroxidation, Journal of Experimental Botany, 32, 1, pp. 79-91.

Flocco, C.G., Lobalbo, A., Cabranza, M.P. \& Guilietti, A.M. (2002). Removal of phenol by alfalfa plants (Medicago sativa L.) grown in hydroponics and its effects on some physiological parameters, Acta Biotechnologica, 22, $1-2$, pp. 43-54.

Gill, S.S. \& Tuteja, N. (2010). Reactive oxygen species and antioxidant machinery in abiotic stress tolerance in crop plants, Plant Physiology and Biochemistry, 48, 12, pp. 909-930.

González, P.S., Ontañon, O.M., Armendariz, A.L., Talano, M.A., Paisio, C.E. \& Agostini, E. (2013). Brassica napus hairy roots and rhizobacteria for phenolic compounds removal, Environmental Science and Pollution Research, 20, 3, pp. 1310-1317.

Hare, P.D. \& Cress, W.A. (1997). Metabolic implications of stress-induced proline accumulation in plants, Plant Growth Regulation, 21, 2, pp. 79-102.
Ibáñez, S.G., Alderete, L.G.S., Medina, M.I. \& Agostini, E. (2012). Phytoremediation of phenol using Vicia sativa L. plants and its antioxidative response, Environmental Science and Pollution Research, 19, 5, pp. 1555-1562.

Jia, L., He, X.Y., Chen, W., Liu, Z.L., Huang, Y.Q. \& Yu, S. (2013). Hormesis phenomena under Cd stress in a hyperaccumulator - Lonicera japonica Thunb, Ecotoxicology, 22, 3, pp. 476-485.

John, R., Ahmad, P., Gadgil, K. \& Sharama, S. (2008). Effect of cadmium and lead on growth, biochemical parameters and uptake in Lemna polyrrhiza L, Plant Soil and Environment, 54, 6, pp. 262-270.

Jordan, W., Van Barnevel, H., Gerlich, O., Kleine, M. \& Ulrico, J. (2002). Ullmann's Encyclopaedia of Industrial Chemistry, Wiley-VCH Verlag, New York 2002.

Kishor, P.B.K., Sangama, S., Amrutha, R.N., Laxmi, P.S., Naidu, K.R., Rao, K.R.S.S., Rao, S., Reddy, K.J., Theriappan, P. \& Sreenivasulu, N. (2005). Regulation of proline biosynthesis degradation, uptake and transport in higher plants: its implications in plant growth and abiotic stress tolerance, Current Science, 88, 3, pp. 424-438.

Kuldeep, B. \& Rana, P.S. (2012). Growth, tolerance efficiency and phytoremediation potential of Ricinus communis L. and Brassica juncea L. in salinity and drought affected cadmium contaminated soil, Ecotoxicology and Environmental Safety, 85, pp. 13-22.

Latef, A.A.H.A. \& He, C.X. (2011). Arbuscular mycorrhizal influence on growth, photosynthetic pigments, osmotic adjustment and oxidative stress in tomato plants subjected to low temperature stress, Acta Physiologiae Plantarum, 33, 4, pp. 1217-1225.

Leslie, S.B., Israeli, E., Lightghart, B., Crowe, J.H. \& Crowe, L.M. (1995). Trehalose and sucrose protect both membranes and proteins in intact bacteria during drying, Applied and Environmental Microbiology, 61, 10, pp. 3592-3597.

Li, H.S., Sun, Q., Zhao, S.J. \& Zhang, W.H. (2000). Principles and techniques of plant physiological biochemical experiment, Higher Education Press, Beijing 2000. (in Chinese)

Li, X.N., Yang, Y.L., Jia, L.Y., Chen, H.J. \& Wei, X. (2013). Zinc-induced oxidative damage, antioxidant enzyme response and proline metabolism in roots and leaves of wheat plant, Ecotoxicology and Environmental Safety, 89, pp. $150-157$.

Lichtenthaler, H.K. \& Wellburn, A.R. (1983). Determinations of total carotenoids and chlorophylls $a$ and $b$ of leaf extracts in different solvents, Biochemical Society Transactions, 11, 5, pp. 591-592.

Liu, X., Peng, K., Wang, A., Lian, C. \& Shen, Z. (2010). Cadmium accumulation and distribution in populations of Phytolacca americana L. and the role of transpiration, Chemosphere, 78, 9, pp. 1136-1141.

Mehta, S.K. \& Gaur, J.P. (1999). Heavy-metal-induced proline accumulation and its role in ameliorating metal toxicity in Chlorella vulgaris, New Phytologist, 143, 2 , pp. 253-259.

Mittler, R. (2002). Oxidative stress, antioxidants and stress tolerance, Trends in Plant Science, 7, 9, pp. 405-410.

Paisio, C., Agostini, E., González, P. \& Bertuzzi, M. (2009). Lethal and teratogenic effects of phenol on Bufo arenarum embryos, Journal of Hazardous Materials, 167, 1-3, pp. 64-68.

Parlak, K.U. \& Yilmaz, D.D. (2013). Ecophysiological tolerance of Lemna gibba L. exposed to cadmium, Ecotoxicology and Environmental Safety, 91, pp. 79-85.

Prado, C., Pagano, E., Prado, F. \& Rose, M. (2012). Detoxification of $\mathrm{Cr}$ (VI) in Salvinia minima is related to seasonal- 
-induced changes of thiols, phenolics and antioxidative enzymes, Journal of Hazardous Materials, 239-240, pp. 355-361.

Scebba, F., Sebastiani, L. \& Vitagliano, C. (1999). Protective enzymes against activated oxygen species in wheat (Triticum aestivum L.) seedlings: Responses to cold acclimation, Journal of Plant Physiology, 155, 6, pp. 762-768.

Sergiev, I., Alexieva, V. \& Karanov, E. (1997). Effect of spermine, atrazine and combination between them on some endogenous protective systems and stress markers in plants, Comptes Rendus de Academie Bulgare des Sciences, 51, 3, pp. 121-124.

Singh, S., Melo, J., Eapen, S. \& D’Souza, S. (2008). Potential of vetiver (Vetiveria zizanoides (L.) Nash) for phytoremediation of phenol, Ecotoxicology and Environmental Safety, 71, 3, pp. 671-676.

Smirnoff, N. (1993). The role of active oxygen in the response of plants to water deficit and desiccation, New Phytologist, 125,1, pp. 27-58

Strzałka, K., Kostecha-Gugała, A. \& Latowski, D. (2003). Carotenoids and environmental stress in plants: significance of carotenoid-mediated modulation of membrane physical properties, Russian Journal of Plant Physiology, 50, 2, pp. $168-172$.

Szabados, L. \& Savoure, A. (2010). Proline: a multifunctional amino acid, Trends in Plant Science, 15, 2, pp. 89-97.

Tayefi-Nasrabadi, H., Dehfhan, G., Daeihassani, B., Movafegi, A. \& Samadi, A. (2011). Some biochemical properties of catalase from safflower (Carthamus tinctorius L. cv. M-cc-190), African Journal of Agricultral Research, 6, 23, pp. 5221-5226.

Tripathi, B.N. \& Gaur, J.P. (2004). Relationship between copper-and zinc-induced oxidative stress and proline accumulation in Scendesmus sp., Planta, 219, 3, pp. 397-404.
Turkan, I., Türkan, İ., Bor, M., Özdemir, F. \& Koca, H. (2005). Differential responses of lipid peroxidation and antioxidants in the leaves of drought tolerant $\mathrm{P}$. acutifolius Gray and drought sensitive P. vulgaris L. subjected to polyethylene glycol mediated water stress, Plant Science, 168, 1, pp. 223-231.

Wang, Y.B., Yan, A.L., Dai, J., Wang, N.N. \& Wu, D. (2012). Accumulation and tolerance characteristics of cadmium in Chlorophytum comosum: a popular ornamental plant and protential $\mathrm{Cd}$ hyperaccumulator, Environmental Monitoring and Assess, 184, 2, pp. 929-937.

Wright, H. \& Nicell, J.A. (1999). Characterization of soybean peroxidase for the treatment of aqueous phenols, Bioresource Technology, 70, 1, pp. 69-79.

Xu, Z.S., Lin, Y.Q., Xu, J., Zhu, B., Zhao, W., Peng, R.H. \& Yao, Q.H. (2013). Selective detoxification of phenols by Pichia pastoris and Arabidopsis thaliana heterologously expressing the PtUG72B1 from populus trichocarpa, Plos one, 8, 6, e66878. Doi: 10.1371/journsl. pron. 0066878.

Yang, Z.Y., Qin, M.J. \& Qian, S.H. (2008). Advances in study on Polygonum orientale L., Chinese Wild Plant Resource, 27, 1, pp. 11-15. (in Chinese)

Yu, D., Ruan, W.Q., Zou, H. \& Yan, Q. (2007). Study on phenol wastewater in anaerobic system, Journal of Food Science and Biotechnology, 26, 5, pp. 84-87. (in Chinese)

Zhang, Q., Zhang, J.Z., Chow, W.S., Sun, L.L., Chen, J.W., Peng, Y. \& Chen, L.C. (2011). The influence of low temperature on photosynthesis and antioxidant enzymes in sensitive banana and tolerant plantain (Musa sp.) cultivars, Photosynthetica, 49, 2, pp. 201-208.

Zhou, Q. (2001). The measurement of malondialdehyde in plants, in: Mehtods in plant physiology, Zhou, Q. (Ed.), pp. 173-174, China Agricultural Press, Beijing 2001. (in Chinese) 